\title{
Metabolic rate and resource depletion in the tick Ixodes ricinus in response to temperature
}

\author{
Saeed Alasmari ${ }^{1} \cdot$ Richard Wall $^{1}$
}

Received: 24 August 2020 / Accepted: 4 November 2020 / Published online: 11 November 2020 (c) The Author(s) 2020

\begin{abstract}
Understanding the effects of temperature on the metabolic activity and the rate of depletion of energy reserves by Ixodes ricinus can represent an important contribution to explaining patterns of tick activity and the likely impacts of environmental change on tick and tick-borne disease risk. Here, a cohort of I. ricinus nymphs, males, and females was collected and placed into incubators at temperatures of between 5 and $30{ }^{\circ} \mathrm{C}$. The protein, carbohydrate, total lipid, neutral lipid, and glycogen levels were measured for nymphs for up to 70 days and adults up to 42 days. In nymphs, at day 0 , glycogen was the most abundant metabolite followed by carbohydrate, with relatively low concentrations of protein and lipids. For males, the concentrations of different metabolites were relatively similar. In contrast, for females, concentrations of glycogen and carbohydrate were relatively low compared to those of protein and neutral lipids. Significant exponential declines in metabolite concentrations of all metabolites were detected over time for all life-cycle stages and at all temperatures. Nymphs generally showed lower rates of resource depletion than adults at all temperatures. The lower thresholds for metabolic activity were estimated to be between -10 and $-5{ }^{\circ} \mathrm{C}$. The $\mathrm{Q}_{10}$ values, which describe the thermal sensitivity of metabolic rate, were estimated to be relatively low (1.5 for nymphs, 1.71 for males, and 1.63 for females) compared to insects where they are typically around 2.5 (range: $1.5-3$ ), and this is considered to be an adaptation to increase survival during the extended inter-feed intervals.
\end{abstract}

Keywords Blood-feeding $\cdot$ Climate change $\cdot$ Ixodes $\cdot$ Metabolite $\cdot$ Temperature threshold

\section{Introduction}

Intermittent blood-feeding and digestion are key behavioural and physiological processes in hard ticks (Ixodidae) that are intimately associated with their role as vectors of pathogens (Randolph 2004). Unlike hematophagous insects, a blood-meal is taken only once by each life-cycle stage: the inter-feed interval is usually several months in univoltine species, ingestion is relatively slow, the volume of blood ingested is relatively large, and digestion is intracellular (Horn et al. 2009; Kongsuwan et al. 2010). Sufficient nutrition must be

Saeed Alasmari

sa16081@bristol.ac.uk

1 School of Biological Sciences, University of Bristol, 24 Tyndall Avenue, Bristol BS8 1TQ, UK 
obtained at each meal and stored within the body to allow larvae and nymphs to undergo development to the next life-cycle stage and eventually initiate repeated questing until another host is located. For adults, accumulated metabolic reserves must also provide the resources for reproduction (Diehl et al. 1982). The longer ticks can survive between bloodmeals, the higher the chance of encountering a new host; hence, the rate at which ticks use accumulated resources during the extensive off-host period is critical to their survival and reproductive success.

The primary immediate energy source for ticks is glucose, which is stored in the hydrated polymeric form of glycogen, but this is rapidly depleted (Moraes et al. 2007). Recent studies have shown that glycogen alone forms $39 \%$ of the mass of metabolites in I. ricinus nymphs compared to 15 and $10 \%$ in females and males, respectively (Alasmari and Wall 2020). Carbohydrate can be used to replenish glycogen reserves. Lipids also play key roles in tick metabolism, both as an energy source and structurally. Lipid is stored primarily the form of triglycerides in adipocytes, the main fat body cell, and additionally as cytoplasmic lipid droplets. Lipid metabolism is particularly associated with growth phases (Arrese and Soulages 2010). The measurement of lipid has been used previously to infer patterns of feeding within cohorts of $I$. ricinus derived from the field (Randolph et al. 2002; Abdullah et al. 2018). Proteins are essential for muscle development and the synthesis of cuticle, hormones and enzymes, synthesis of egg yolk and the production of sperm and gonadal proteins (Kongsuwan et al. 2010). Proteins may also be metabolised as a long-term energy reserve (Williams et al. 1986).

Patterns of metabolic activity are not uniform throughout life and increases are associated with feeding and moulting, followed by reduced levels of metabolic activity and energy utilisation for several weeks (Cuber et al. 2016). However, once energy levels have been depleted, the levels of activity and energy expenditure then increase as questing becomes more prolonged and increasingly persistent, and this makes ticks highly susceptible to environmental stresses such as dehydration (MacLeod 1935; Needham and Teel 1991; Bowman et al. 1996). The intermittent feeding of hard ticks is a relatively high-risk life-history strategy, and mortality rates in each life-cycle stage associated with questing must be counterbalanced, in terms of fitness, by the benefits from the reduced risk of injury gained by not spending long periods on an actively grooming host.

Strong non-linear relationships between temperature and many aspects of tick life-history have been demonstrated, although this relationship is not a simple one because saturation deficit will affect desiccation (Needham and Teel 1991) and temperature, in combination with day length, may affect various forms of behavioural or physiological diapause (Belozerov 2009). For example, researches on Ixodes scapularis have found that the power relationships observed between temperature and development rate in the laboratory could be used to predict dates for moulting, oviposition, and field-observed seasonal questing in larvae and nymphs, (Ogden et al. 2004; Burtis et al. 2019). However, other factors, such as the seasonal activity of questing adult ticks, were poorly predicted. An understanding of the pattern of metabolite use and depletion, particularly in responses to factors such as temperature, is important, not only to explain tick population dynamics and phenology, but also because it may contribute to a better understanding of the likely impacts of climatic changes on ticks, since this is likely to affect seasonal activity patterns and, consequently, may affect pathogen transmission (Gray et al. 2009; Burtis et al. 2016).

Energy budgets and factors affecting metabolic rate have been extensively studied in insects (Satake et al. 2000; Chown and Nicolson 2004) but are much less well understood in ticks. The study of metabolite concentrations and depletion has been greatly facilitated by the spectrophotometric techniques developed by van Handel (1985a, b), and recent studies have demonstrated that these methods can also be used to determine the entire energy 
budget of individual ticks (Alasmari and Wall 2020). The aim of the work described here was therefore to investigate the effects of temperature on the rate of depletion of metabolic reserves over time in nymphs and adults of I. ricinus collected from the field.

\section{Materials and methods}

\section{Tick collection and environmental conditions}

A total of 2160 ticks were collected from Ashton Court Park near Bristol on a single day (day -14) in the middle of March 2019. The samples collected were temporarily stored at $4{ }^{\circ} \mathrm{C}$ for $6 \mathrm{~h}$ before being divided into groups based on life-cycle stage. Nymphs, adult males, and adult females of I. ricinus were then divided into six groups of 100-150 individuals, which were transferred into 1.2-1 plastic buckets with tightly fitting lids $(12.5 \times 18 \mathrm{~cm})$. Each bucket contained $3 \mathrm{~kg}$ of dampened horticultural silver sand (Melcourt, Tetbury, UK) to raise the humidity experienced by the ticks to $>80 \%$; humidity was not controlled further, but conditions were similar for all groups and humidity was sufficiently high to allow high survival at all temperatures. All buckets were placed in incubators (Sanyo, MLR-351) set at temperatures of 5, 10, 15, 20, 25, and $30{ }^{\circ} \mathrm{C}$, and kept under diel periods of L8:D16 h. A relatively short photoperiod was used to reflect the time of year when the ticks were collected, as a change from short to long daylight could influence physiological changes associated with diapause (Gray et al. 2016). Ticks were initially maintained under these conditions for 2 weeks before the experiment was considered to have started (day 0) to allow them to adapt to their new laboratory environment. For nymphs, the concentrations of protein, carbohydrate, total lipid, neutral lipid, and glycogen were measured at days $0,14,28,42,56$, and 70 . For the adult males and females, the measurements of the same metabolites were performed on days $0,14,28$, and 42 only.

\section{Biochemical measurements}

The spectrophotometric methods used were as described in Alasmari and Wall (2020) based on those developed by van Handel (1985a, b). In brief, for the protein analysis, the ticks were first individually placed in a sterilised borosilicate tube $(12 \mathrm{ml})$ and crushed with a clean glass rod. Next, $1500 \mu \mathrm{l}$ of a phosphate buffer solution [100 mM of monopotassium phosphate, $1 \mathrm{mM}$ of ethylenediaminetetraacetic acid, and $1 \mathrm{mM}$ of dithiothreitol (pH 7.4)] was added to extract the protein component. Thereafter, the homogenate was placed on ice (for about $1 \mathrm{~min}$ ) prior to processing. For the nymphs, $1000 \mu \mathrm{l}$ of the homogenate was transferred to a cuvette and mixed with $1000 \mu \mathrm{l}$ of Bradford reagent (Sigma, Dorset, UK). For the adult males and females, because the sample size was smaller, $50 \mu$ of the homogenate was transferred to a cuvette and mixed with $1500 \mu$ of Bradford reagent. Individual cuvettes were incubated at room temperature for $5 \mathrm{~min}$, after which the absorbance was immediately measured at a wavelength of $595 \mathrm{~nm}$ using a spectrophotometer (Biochrom Biowave II, Cambridge, UK).

For the analysis of the other metabolites, a single individual tick was placed in a clean borosilicate tube and crushed, as described above. To dissolve water-soluble carbohydrates and the total fats, $200 \mu \mathrm{l}$ of $2 \%$ sodium sulphate solution (VWR International, Leicestershire, UK) and $1500 \mu \mathrm{l}$ of a chloroform/methanol mixture $(1: 2$, vol/vol) were added to each tube. This solution was transferred into a 2-ml Eppendorf tube and centrifuged (Eppendorf 
Centrifuge 5418R; Lutterworth, UK) for $15 \mathrm{~min}$ at $180 \times g$ at $4{ }^{\circ} \mathrm{C}$. For the analysis of the total lipids, neutral lipids and carbohydrates, the supernatant was transferred to a new tube.

For the carbohydrate analysis, $200 \mu \mathrm{l}$ of the supernatant from individual samples was transferred to a borosilicate tube and placed in a water bath at $90{ }^{\circ} \mathrm{C}$ for $40 \mathrm{~s}$ so that the solvent would evaporate; this was done until about $20 \mu \mathrm{l}$ was left. Thereafter, $1 \mathrm{ml}$ of freshly prepared anthrone reagent (Sigma) at a concentration of $1.42 \mathrm{~g} / \mathrm{l}$ of $70 \%$ sulphuric acid (VWR International) was added to each sample and incubated for $15 \mathrm{~min}$ at $25{ }^{\circ} \mathrm{C}$. Subsequently, the tubes were heated for $15 \mathrm{~min}$ at $90{ }^{\circ} \mathrm{C}$ and cooled at room temperature for $15 \mathrm{~min}$. Then, the samples were placed in a microcuvette and read in a spectrophotometer at an absorbance wavelength of $625 \mathrm{~nm}$.

For the glycogen analysis, the pellets were washed twice with $400 \mu \mathrm{l}$ of $80 \%$ methanol to remove sodium sulphate. Then, vigorous vortexing was performed at full speed for up to $20 \mathrm{~s}$; this was followed by centrifugation for $5 \mathrm{~min}$ at $180 \times g$ and $4{ }^{\circ} \mathrm{C}$. Once the supernatant was removed, $1 \mathrm{ml}$ of fresh anthrone reagent was added, and the mixture was incubated at $90{ }^{\circ} \mathrm{C}$ for $15 \mathrm{~min}$. The samples were cooled on ice to stop the reaction and filtered through low-protein-binding membranes with a pore diameter of $0.45 \mu \mathrm{m}$ (Fisher Scientific, Leicestershire, UK). Finally, the absorbance was read with a spectrophotometer at a wavelength of $625 \mathrm{~nm}$.

The total lipids were quantified using a vanillin assay. For this assay, $200 \mu \mathrm{l}$ of the supernatant was added into a new borosilicate tube that was placed in a heating block at $90{ }^{\circ} \mathrm{C}$ until total evaporation was achieved. Then, $40 \mu \mathrm{l}$ of $95 \%$ sulphuric acid (VWR International) was added to the residue in the tube, heated at $90{ }^{\circ} \mathrm{C}$ for $2 \mathrm{~min}$, and cooled on ice. Next, $960 \mu \mathrm{l}$ of the freshly prepared $1.2 \mathrm{~g} / \mathrm{l}$ vanillin reagent (Fisher Scientific) in 68\% phosphoric acid (Sigma) was added, and the solution was incubated at room temperature for $15 \mathrm{~min}$. Absorbance was read with a spectrophotometer set to a wavelength of $525 \mathrm{~nm}$.

The neutral lipid content was measured by placing $500 \mu \mathrm{l}$ of the supernatant in a new tube that was heated at $90{ }^{\circ} \mathrm{C}$; this was done until the solvent had completely evaporated. Next, $1 \mathrm{ml}$ of chloroform was added, and the solution was transferred to a new tube. Next, the fats were resolubilised by adding $200 \mathrm{mg}$ of dry silicic acid (Sigma) to each sample and mixing. The mixed solution was then centrifuged at $180 \times g$ at $4{ }^{\circ} \mathrm{C}$ for $10 \mathrm{~min}$ to remove any polar lipids present in the silicic acid. From the final supernatant, $200 \mu \mathrm{l}$ was transferred to a new tube using a pipette. The procedure above was repeated, and the absorbance was read with a spectrophotometer set to a wavelength of $525 \mathrm{~nm}$. For each temperature condition, extractions were performed on 12 nymphs, 12 adult males, and 12 adult females.

\section{Standard curves}

Standard curves of the absorbance of known metabolite concentrations were created so that the measured spectrophotometric values could be used to determine the corresponding metabolite concentrations. Care was taken to ensure that the relationship between the concentrations and the spectrophotometric values was linear and that the curves covered the entire range of the measured concentrations (from below the lowest value to the highest value). For determining the protein concentration, a standard curve was generated with a dilution series of bovine serum albumin $(1 \mathrm{mg} / \mathrm{ml}$; Sigma) that was treated as described above. For determining the carbohydrate and glycogen concentrations, a standard curve was generated using glucose ( $1 \mathrm{mg} / \mathrm{ml}$; Sigma) at a range of dilutions. For the lipid analysis, a standard curve was generated using glycerol trioleate $(1 \mathrm{mg} / \mathrm{ml}$; Sigma) at different dilutions. Five independent repeats of different serial dilutions were conducted to produce each standard curve. 


\section{Data analysis}

Analyses were performed with the R-Studio statistical package v.3.5.3 (R Foundation for Statistical Computing, Vienna, Austria) and SPSS v.26 (IBM SPSS Statistics, Armonk, NY, USA). The relationships between metabolite concentration and time and the rate of metabolite depletion and temperature were determined by best-fit regression analysis and differences between metabolite concentrations by one- and two-way ANOVA with Tukey post-hoc tests.

\section{Results}

\section{Initial metabolite concentrations}

At day 0 , there were highly significant differences in the concentrations of metabolites present $\left(\mathrm{F}_{4,1074}=262.87, \mathrm{P}<0.001\right)$ for all life cycle stages $\left(\mathrm{F}_{2,1074}=791.7, \mathrm{P}<0.001\right)$ with a significant interaction between metabolite and life cycle stage $\left(\mathrm{F}_{8,1074}=227.9, \mathrm{P}<0.001\right.$; Fig. 1). In nymphs, glycogen was the most abundant metabolite, followed by carbohydrate, with relatively low concentrations of protein and lipid $\left(\mathrm{F}_{4,355}=459.0, \mathrm{P}<0.001\right)$, with no significant difference between the concentrations of neutral lipid and phospholipid.

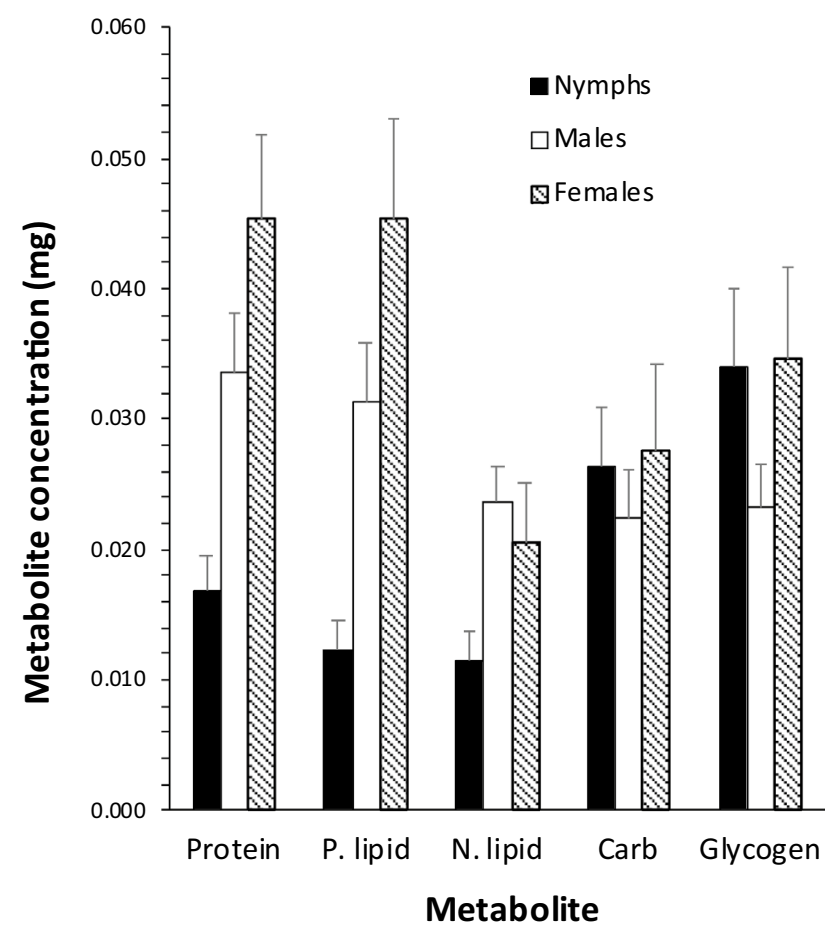

Fig. 1 Mean $( \pm S D)$ concentrations of protein, phospholipid (p. lipid), neutral lipid (n. lipid), carbohydrate (carb) and glycogen at day 0 , found in nymphal, male, and female Ixodes ricinus ticks collected by blanket dragging in March, 2019 
For males, the concentrations of metabolites were relatively more even, with no significant difference between the concentrations of neutral lipid, carbohydrate, and glycogen, which were significantly lower than the concentrations of phospholipid and protein $\left(\mathrm{F}_{4,360}\right.$ $=132.9, \mathrm{P}<0.001$; Fig. 11. In contrast, for females, relatively high concentrations of protein and neutral lipid were present at concentrations that were not significantly different from each other but were higher than other metabolites, which were all different from each other $\left(\mathrm{F}_{4,360}=202.8, \mathrm{P}<0.001\right.$; Fig. 1).

\section{Metabolite depletion over time}

Significant exponential declines in metabolite concentrations were detected over time for all life-cycle stages and at all temperatures (Tables 1, 2 and 3). The slopes of the regressions indicate that nymphs generally show lower rates of resource depletion than adults at all temperatures. The overall mean $( \pm \mathrm{SD})$ rate of depletion was $0.016 \pm 0.0058 \mathrm{mg} / \mathrm{day}$ for nymphs, $0.019 \pm 0.0085$ for males, and $0.023 \pm 0.0088$ for females. Over a period of 42 days at $5{ }^{\circ} \mathrm{C}$, nymphs lost an average of $25 \%$ of their initial metabolite mass. In contrast, at the same temperature and over the same time period, adults showed losses of on average $35 \%$ for males and $40 \%$ for females. At $30{ }^{\circ} \mathrm{C}$ nymphs lost an average of $55 \%$ of their initial metabolite mass over 42 days, whereas adults lost an average of 73 and $78 \%$ for males and females, respectively. Extrapolation from these results suggests that starvation would occur at between 50 and 70 days at $25-30{ }^{\circ} \mathrm{C}$ and $100-200$ days at $5{ }^{\circ} \mathrm{C}$.

\section{Metabolite depletion with temperature}

The slopes of the relationships between metabolite concentration and time describe the rate of loss of each class of compound (mg/day). A plot of the slope of the relationship between metabolite concentration and time against temperature therefore describes the relationship between the rate of loss of each compound class and temperature (Fig. 2). Consistent patterns in the rate of use of particular metabolites were evident between different life-cycle stages. For nymphs, the rates of use of neutral lipid and glycogen were consistently high and the rate of loss of protein was low, particularly at low temperatures. In contrast, for males, carbohydrate concentrations declined most rapidly and glycogen the least. Finally, for females, there was much less variation in the rate of metabolite use compared to males or nymphs but a consistent pattern emerged, with lipid concentrations declining at a higher rate than other metabolites. The $\mathrm{Q}_{10}$ values, determined from a linear regression fitted to all the metabolite data (Fig. 2), gave values of 1.5 for nymphs, 1.71 for males, and 1.63 for females. Extrapolation of this linear regression indicates that the lower temperature threshold for metabolic activity in $I$. ricinus for is $-8.8{ }^{\circ} \mathrm{C}$ for nymphs, $-4.1{ }^{\circ} \mathrm{C}$ for males, and $-5.9{ }^{\circ} \mathrm{C}$ for females.

\section{Discussion}

Metabolic rate and changes in the rates of metabolite use are associated with extrinsic factors such as temperature and humidity and intrinsic factors associated with feeding, moulting, and reproduction. Understanding how these factors influence changes in 
Table 1 Relationships between concentration for each metabolic component and time (days) for Ixodes ricinus (nymphs) that were maintained at temperatures of 5 to $30{ }^{\circ} \mathrm{C}$, with the equation of the best fit negative exponential line, $\mathrm{R}^{2}, \mathrm{~F}$, and significance of the regression $(\mathrm{P})$

\begin{tabular}{|c|c|c|c|c|c|}
\hline \multirow[t]{2}{*}{ Metabolic components } & \multirow{2}{*}{$\begin{array}{l}\text { Temperature } \\
\left({ }^{\circ} \mathrm{C}\right)\end{array}$} & \multicolumn{4}{|l|}{ Regression } \\
\hline & & Equation & $\mathrm{R}^{2}$ & $\mathrm{~F}$ & $P$ \\
\hline \multirow[t]{6}{*}{ Protein } & 5 & $y=0.0179 e^{-0.008 x}$ & 0.62 & 118 & 0.0001 \\
\hline & 10 & $y=0.0171 e^{-0.009 x}$ & 0.59 & 101.3 & 0.0001 \\
\hline & 15 & $\mathrm{y}=0.0165 \mathrm{e}^{-0.010 \mathrm{x}}$ & 0.71 & 178.7 & 0.0001 \\
\hline & 20 & $y=0.0168 e^{-0.013 x}$ & 0.74 & 208.6 & 0.0001 \\
\hline & 25 & $\mathrm{y}=0.0161 \mathrm{e}^{-0.017 \mathrm{x}}$ & 0.81 & 304.4 & 0.0001 \\
\hline & 30 & $\mathrm{y}=0.0176 \mathrm{e}^{-0.023 \mathrm{x}}$ & 0.83 & 348.4 & 0.0001 \\
\hline \multirow[t]{6}{*}{ Phospholipid } & 5 & $y=0.013 e^{-0.008 x}$ & 0.47 & 63.3 & 0.0001 \\
\hline & 10 & $y=0.0125 e^{-0.009 x}$ & 0.58 & 96.86 & 0.0001 \\
\hline & 15 & $\mathrm{y}=0.0126 \mathrm{e}^{-0.011 \mathrm{x}}$ & 0.74 & 205.7 & 0.0001 \\
\hline & 20 & $\mathrm{y}=0.0122 \mathrm{e}^{-0.015 \mathrm{x}}$ & 0.72 & 181.5 & 0.0001 \\
\hline & 25 & $\mathrm{y}=0.0125 \mathrm{e}^{-0.018 \mathrm{x}}$ & 0.82 & 326.1 & 0.0001 \\
\hline & 30 & $\mathrm{y}=0.0125 \mathrm{e}^{-0.022 \mathrm{x}}$ & 0.78 & 254.9 & 0.0001 \\
\hline \multirow[t]{6}{*}{ Neutral lipid } & 5 & $\mathrm{y}=0.0126 \mathrm{e}^{-0.012 \mathrm{x}}$ & 0.64 & 124.5 & 0.0001 \\
\hline & 10 & $\mathrm{y}=0.0128 \mathrm{e}^{-0.014 \mathrm{x}}$ & 0.66 & 140.2 & 0.0001 \\
\hline & 15 & $\mathrm{y}=0.0126 \mathrm{e}^{-0.017 \mathrm{x}}$ & 0.75 & 212.2 & 0.0001 \\
\hline & 20 & $\mathrm{y}=0.0128 \mathrm{e}^{-0.021 \mathrm{x}}$ & 0.74 & 208.8 & 0.0001 \\
\hline & 25 & $\mathrm{y}=0.0118 \mathrm{e}^{-0.023 \mathrm{x}}$ & 0.84 & 378.8 & 0.0001 \\
\hline & 30 & $y=0.0123 e^{-0.028 x}$ & 0.85 & 399.3 & 0.0001 \\
\hline \multirow[t]{6}{*}{ Carbohydrate } & 5 & $y=0.0283 e^{-0.007 x}$ & 0.46 & 61.33 & 0.0001 \\
\hline & 10 & $\mathrm{y}=0.0294 \mathrm{e}^{-0.011 \mathrm{x}}$ & 0.65 & 131.3 & 0.0001 \\
\hline & 15 & $y=0.0289 e^{-0.013 x}$ & 0.64 & 127.5 & 0.0001 \\
\hline & 20 & $y=0.0291 e^{-0.015 x}$ & 0.70 & 169.2 & 0.0001 \\
\hline & 25 & $\mathrm{y}=0.0295 \mathrm{e}^{-0.018 \mathrm{x}}$ & 0.76 & 223.8 & 0.0001 \\
\hline & 30 & $\mathrm{y}=0.0327 \mathrm{e}^{-0.024 \mathrm{x}}$ & 0.80 & 286.9 & 0.0001 \\
\hline \multirow[t]{6}{*}{ Glycogen } & 5 & $\mathrm{y}=0.0336 \mathrm{e}^{-0.009 \mathrm{x}}$ & 0.58 & 100.6 & 0.0001 \\
\hline & 10 & $\mathrm{y}=0.035 \mathrm{e}^{-0.013 \mathrm{x}}$ & 0.73 & 193 & 0.0001 \\
\hline & 15 & $\mathrm{y}=0.0342 \mathrm{e}^{-0.015 \mathrm{x}}$ & 0.74 & 206.4 & 0.0001 \\
\hline & 20 & $\mathrm{y}=0.0352 \mathrm{e}^{-0.017 \mathrm{x}}$ & 0.83 & 349.7 & 0.0001 \\
\hline & 25 & $\mathrm{y}=0.0353 \mathrm{e}^{-0.02 \mathrm{x}}$ & 0.83 & 345.3 & 0.0001 \\
\hline & 30 & $\mathrm{y}=0.0386 \mathrm{e}^{-0.027 \mathrm{x}}$ & 0.83 & 360.7 & 0.0001 \\
\hline
\end{tabular}

metabolic rate and resource depletion are important for explaining patterns of tick phenology in the field and for prediction of changes in distribution and abundance that may occur in response to environmental change (Hancock et al. 2011).

The ticks used for the present study were collected by blanket dragging in March 2019. At this time of year, questing activity of nymphs and adults in southwest England would be expected to be at its peak. Populations of nymphs and adults would largely be composed of cohorts which fed the previous year and either moulted the previous autumn or which overwintered and moulted in early spring prior to collection, depending on 
Table 2 Relationships between concentration for each metabolic component and time (days) for Ixodes ricinus (males) that were maintained at temperatures of 5 to $30{ }^{\circ} \mathrm{C}$, with the equation of the best fit negative exponential line, $\mathrm{R}^{2}, \mathrm{~F}$, and significance of the regression $(\mathrm{P})$

\begin{tabular}{|c|c|c|c|c|c|}
\hline \multirow[t]{2}{*}{ Metabolic components } & \multirow{2}{*}{$\begin{array}{l}\text { Temperature } \\
\left({ }^{\circ} \mathrm{C}\right)\end{array}$} & \multicolumn{4}{|l|}{ Regression } \\
\hline & & Equation & $\mathrm{R}^{2}$ & $\mathrm{~F}$ & $\mathrm{P}$ \\
\hline \multirow[t]{6}{*}{ Protein } & 5 & $y=0.0337 e^{-0.006 x}$ & 0.24 & 14.81 & 0.0003 \\
\hline & 10 & $y=0.0335 \mathrm{e}^{-0.009 x}$ & 0.50 & 46.52 & 0.0001 \\
\hline & 15 & $\mathrm{y}=0.0342 \mathrm{e}^{-0.013 \mathrm{x}}$ & 0.65 & 87.07 & 0.0001 \\
\hline & 20 & $y=0.0329 e^{-0.016 x}$ & 0.70 & 107 & 0.0001 \\
\hline & 25 & $y=0.0317 e^{-0.022 x}$ & 0.78 & 167.1 & 0.0001 \\
\hline & 30 & $\mathrm{y}=0.0308 \mathrm{e}^{-0.028 \mathrm{x}}$ & 0.76 & 146.3 & 0.0001 \\
\hline \multirow[t]{6}{*}{ Phospholipid } & 5 & $\mathrm{y}=0.0334 \mathrm{e}^{-0.008 \mathrm{x}}$ & 0.37 & 28.02 & 0.0001 \\
\hline & 10 & $\mathrm{y}=0.0323 \mathrm{e}^{-0.012 \mathrm{x}}$ & 0.56 & 58.95 & 0.0001 \\
\hline & 15 & $\mathrm{y}=0.0315 \mathrm{e}^{-0.017 \mathrm{x}}$ & 0.64 & 82.44 & 0.0001 \\
\hline & 20 & $\mathrm{y}=0.03 \mathrm{e}^{-0.023 \mathrm{x}}$ & 0.80 & 190.6 & 0.0001 \\
\hline & 25 & $\mathrm{y}=0.0288 \mathrm{e}^{-0.029 \mathrm{x}}$ & 0.75 & 139.4 & 0.0001 \\
\hline & 30 & $y=0.0289 e^{-0.033 x}$ & 0.84 & 249.8 & 0.0001 \\
\hline \multirow[t]{6}{*}{ Neutral lipid } & 5 & $y=0.0238 e^{-0.009 x}$ & 0.33 & 23.09 & 0.0001 \\
\hline & 10 & $\mathrm{y}=0.0233 \mathrm{e}^{-0.013 \mathrm{x}}$ & 0.48 & 42.83 & 0.0001 \\
\hline & 15 & $y=0.0231 e^{-0.016 x}$ & 0.66 & 89.92 & 0.0001 \\
\hline & 20 & $y=0.0213 e^{-0.02 x}$ & 0.61 & 72.78 & 0.0001 \\
\hline & 25 & $\mathrm{y}=0.0206 \mathrm{e}^{-0.025 \mathrm{x}}$ & 0.64 & 84.72 & 0.0001 \\
\hline & 30 & $y=0.0207 e^{-0.035 x}$ & 0.79 & 174.6 & 0.0001 \\
\hline \multirow[t]{6}{*}{ Carbohydrate } & 5 & $\mathrm{y}=0.0224 \mathrm{e}^{-0.012 \mathrm{x}}$ & 0.48 & 42.81 & 0.0001 \\
\hline & 10 & $\mathrm{y}=0.023 \mathrm{e}^{-0.017 \mathrm{x}}$ & 0.65 & 85.65 & 0.0001 \\
\hline & 15 & $\mathrm{y}=0.0227 \mathrm{e}^{-0.021 \mathrm{x}}$ & 0.73 & 129.3 & 0.0001 \\
\hline & 20 & $y=0.0221 e^{-0.025 x}$ & 0.73 & 126.5 & 0.0001 \\
\hline & 25 & $\mathrm{y}=0.0226 \mathrm{e}^{-0.030 \mathrm{x}}$ & 0.80 & 193.7 & 0.0001 \\
\hline & 30 & $\mathrm{y}=0.0218 \mathrm{e}^{-0.033 \mathrm{x}}$ & 0.80 & 194.1 & 0.0001 \\
\hline \multirow[t]{6}{*}{ Glycogen } & 5 & $y=0.0239 e^{-0.008 x}$ & 0.24 & 15.21 & 0.0003 \\
\hline & 10 & $y=0.0228 e^{-0.008 x}$ & 0.39 & 29.47 & 0.0001 \\
\hline & 15 & $\mathrm{y}=0.0229 \mathrm{e}^{-0.012 \mathrm{x}}$ & 0.40 & 31.32 & 0.0001 \\
\hline & 20 & $y=0.0231 e^{-0.014 x}$ & 0.43 & 35.19 & 0.0001 \\
\hline & 25 & $\mathrm{y}=0.0225 \mathrm{e}^{-0.018 \mathrm{x}}$ & 0.61 & 75.03 & 0.0001 \\
\hline & 30 & $y=0.0223 e^{-0.024 x}$ & 0.74 & 131.2 & 0.0001 \\
\hline
\end{tabular}

precisely when they had fed. Amongst the ticks collected, at experimental day 0, clear differences in metabolite concentrations between life cycle stages were apparent: these were largely associated with the differences in the relative amounts of protein compared to glycogen. In nymphs, glycogen represented $34 \%$ of the total mass of metabolites measures, followed by carbohydrate at $26 \%$, whereas protein represented only $16 \%$ of the mass of metabolites present in nymphs. In contrast, glycogen composed only $12 \%$ of the mass of metabolites in females and $18 \%$ in males, whereas protein represented $26 \%$ of the mass in females and $25 \%$ in males. These differences are consistent with those recorded previously (Alasmari and Wall 2020). The relatively low glycogen and carbohydrate levels in adults 
Table 3 Relationships between concentration for each metabolic component and time (days) for Ixodes ricinus (females) that were maintained at temperatures of 5 to $30{ }^{\circ} \mathrm{C}$, with the equation of the best fit negative exponential line, $\mathrm{R}^{2}, \mathrm{~F}$, and significance of the regression $(\mathrm{P})$

\begin{tabular}{|c|c|c|c|c|c|}
\hline \multirow[t]{2}{*}{ Metabolic components } & \multirow{2}{*}{$\begin{array}{l}\text { Temperature } \\
\left({ }^{\circ} \mathrm{C}\right)\end{array}$} & \multicolumn{4}{|l|}{ Regression } \\
\hline & & Equation & $\mathrm{R}^{2}$ & $\mathrm{~F}$ & $\mathrm{P}$ \\
\hline \multirow[t]{6}{*}{ Protein } & 5 & $y=0.0456 e^{-0.011 x}$ & 0.47 & 41.98 & 0.0001 \\
\hline & 10 & $y=0.0476 e^{-0.016 x}$ & 0.56 & 59.39 & 0.0001 \\
\hline & 15 & $y=0.0488 e^{-0.021 x}$ & 0.70 & 110.4 & 0.0001 \\
\hline & 20 & $y=0.0497 e^{-0.025 x}$ & 0.80 & 187.1 & 0.0001 \\
\hline & 25 & $\mathrm{y}=0.05 \mathrm{e}^{-0.031 \mathrm{x}}$ & 0.79 & 181.7 & 0.0001 \\
\hline & 30 & $y=0.0507 e^{-0.036 x}$ & 0.84 & 259.5 & 0.0001 \\
\hline \multirow[t]{6}{*}{ Phospholipid } & 5 & $y=0.0467 e^{-0.011 x}$ & 0.56 & 59.16 & 0.0001 \\
\hline & 10 & $y=0.0461 e^{-0.016 x}$ & 0.61 & 72.32 & 0.0001 \\
\hline & 15 & $y=0.0469 e^{-0.021 x}$ & 0.69 & 105.1 & 0.0001 \\
\hline & 20 & $y=0.0463 e^{-0.024 x}$ & 0.74 & 132.8 & 0.0001 \\
\hline & 25 & $\mathrm{y}=0.0458 \mathrm{e}^{-0.031 \mathrm{x}}$ & 0.78 & 170.6 & 0.0001 \\
\hline & 30 & $y=0.0482 e^{-0.036 x}$ & 0.87 & 309.8 & 0.0001 \\
\hline \multirow[t]{6}{*}{ Neutral lipid } & 5 & $y=0.0205 e^{-0.014 x}$ & 0.50 & 47.14 & 0.0001 \\
\hline & 10 & $y=0.0205 e^{-0.018 x}$ & 0.56 & 60.57 & 0.0001 \\
\hline & 15 & $y=0.0201 e^{-0.021 x}$ & 0.61 & 73.19 & 0.0001 \\
\hline & 20 & $y=0.0206 e^{-0.029 x}$ & 0.68 & 100.8 & 0.0001 \\
\hline & 25 & $\mathrm{y}=0.0206 \mathrm{e}^{-0.033 \mathrm{x}}$ & 0.75 & 140.2 & 0.0001 \\
\hline & 30 & $y=0.0202 \mathrm{e}^{-0.042 \mathrm{x}}$ & 0.80 & 191.7 & 0.0001 \\
\hline \multirow[t]{6}{*}{ Carbohydrate } & 5 & $\mathrm{y}=0.0262 \mathrm{e}^{-0.011 \mathrm{x}}$ & 0.28 & 18.08 & 0.0001 \\
\hline & 10 & $y=0.0267 e^{-0.014 x}$ & 0.45 & 38.41 & 0.0001 \\
\hline & 15 & $y=0.0275 e^{-0.018 x}$ & 0.59 & 66.3 & 0.0001 \\
\hline & 20 & $\mathrm{y}=0.0276 \mathrm{e}^{-0.021 \mathrm{x}}$ & 0.56 & 60.73 & 0.0001 \\
\hline & 25 & $y=0.0279 e^{-0.026 x}$ & 0.72 & 119.5 & 0.0001 \\
\hline & 30 & $y=0.0275 e^{-0.034 x}$ & 0.76 & 146.7 & 0.0001 \\
\hline \multirow[t]{6}{*}{ Glycogen } & 5 & $\mathrm{y}=0.0362 \mathrm{e}^{-0.013 \mathrm{x}}$ & 0.49 & 44.39 & 0.0001 \\
\hline & 10 & $\mathrm{y}=0.0356 \mathrm{e}^{-0.014 \mathrm{x}}$ & 0.57 & 62.8 & 0.0001 \\
\hline & 15 & $y=0.0344 e^{-0.016 x}$ & 0.60 & 70.12 & 0.0001 \\
\hline & 20 & $\mathrm{y}=0.0333 \mathrm{e}^{-0.021 \mathrm{x}}$ & 0.58 & 64.28 & 0.0001 \\
\hline & 25 & $\mathrm{y}=0.0337 \mathrm{e}^{-0.031 \mathrm{x}}$ & 0.69 & 105.8 & 0.0001 \\
\hline & 30 & $y=0.0317 e^{-0.033 x}$ & 0.74 & 135 & 0.0001 \\
\hline
\end{tabular}

may be associated with the fact that the adult population is composed predominantly of individuals that fed as nymphs early the previous year and moulted the previous autumn and so by March are relatively resource depleted (Randolph et al. 2002; Abdullah et al. 2018). In contrast, the nymphs may be derived from larvae that fed later in the previous year and may have moulted in late autumn or early spring and so have relatively higher energy reserves and particularly are richer in glycogen and carbohydrate. This hypothesis could be tested by examining the full metabolite profile of adults collected at different times, particularly in late autumn. If this is correct, over time, because nymphs were relatively better resourced with higher initial short-term energy resources, their lipid and 

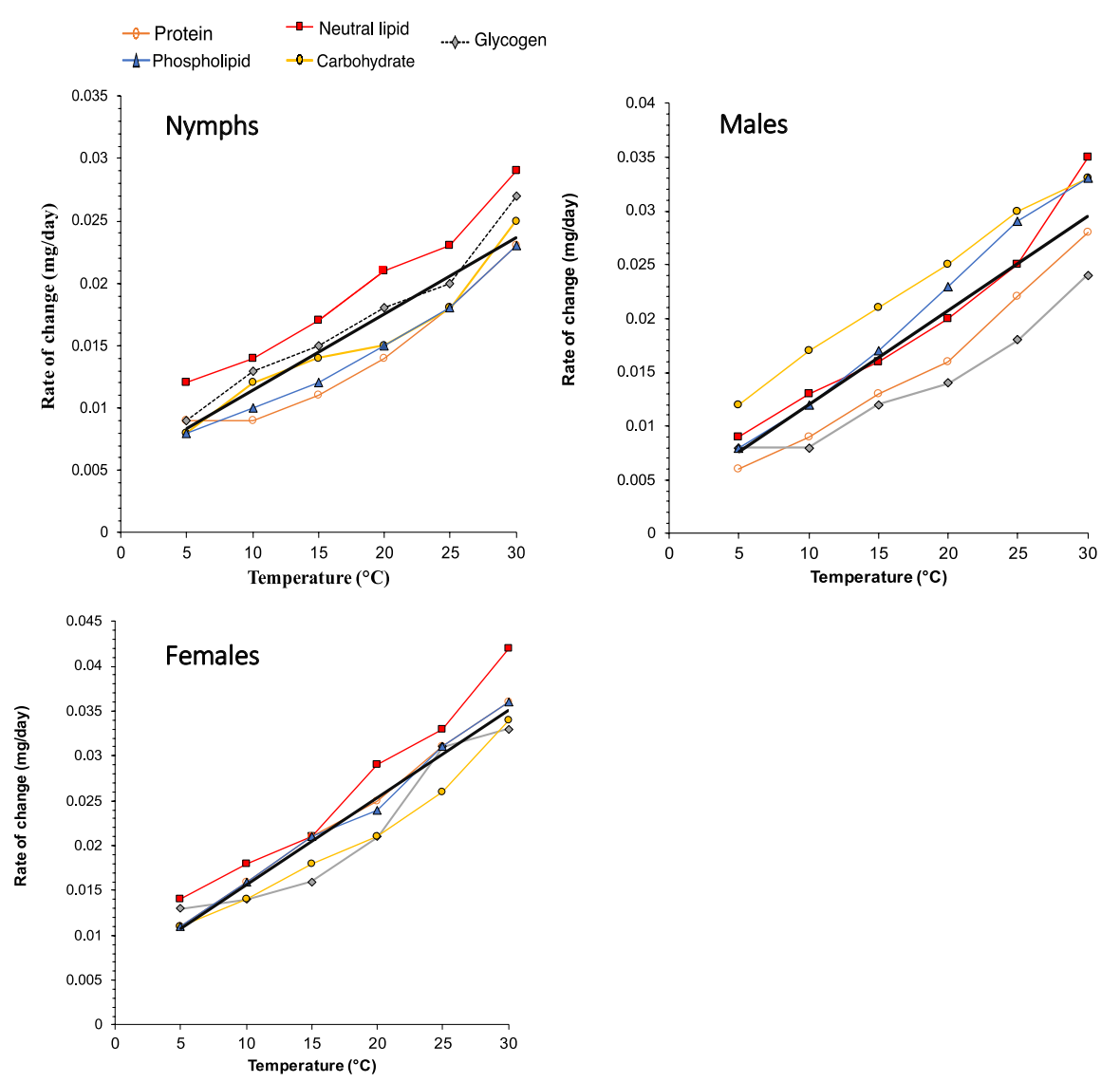

Fig. 2 Rate of change of various metabolites over time in Ixodes ricinus nymphs, males, and females at 5-30 ${ }^{\circ} \mathrm{C}$. Points are joined for clarity. The solid black lines indicate the best fit linear regression fitted to all data (nymphs: $\mathrm{Y}=0.0006 \mathrm{X}+0.0053, \mathrm{R}^{2}=0.834$; males: $\mathrm{Y}=0.0009 \mathrm{X}+0.0033, \mathrm{R}^{2}=0.804$; females: $\mathrm{Y}=0.001 \mathrm{X}+0.0059, \mathrm{R}^{2}=0.916$, all $\left.\mathrm{P}<0.001\right)$

glycogen rates of depletion would be higher than those of other metabolites and their rate of protein loss would be low. In contrast to nymphs, for adults, males were depleting carbohydrate and lipid at the highest rates, whereas in females the highest rates of depletion were seen in lipid and protein concentrations; in adults, the rates of glycogen depletion were relatively low because their initial glycogen concentrations available at day 0 were also relatively low. The rate of depletion of each metabolite during the trial was relatively constant in response to temperature and was best described by an exponential model. No major changes in the rank order of the rates of metabolite depletion over time in response to changes in temperature could be detected, although this might have been predicted in nymphs as they depleted their glycogen and carbohydrate reserves. Examination of a full season-long metabolic profile in tick cohorts would be a useful next step.

In a study that considered only stored lipids, the lipid reserves of field-collected $I$. ricinus nymphs, collected in early summer, were estimated to be sufficient to allow survival without feeding for up to 100 to 250 days at $15{ }^{\circ} \mathrm{C}$, depending on whether they had fed as larvae the previous autumn or that year, respectively (Abdullah et al. 2018). 
Here, the results suggest that, amongst the cohort collected, complete resource depletion would occur at $45-70$ days at $25-30{ }^{\circ} \mathrm{C}$ and 200 days at $5{ }^{\circ} \mathrm{C}$, assuming humidity was sufficiently high not to result in desiccation. This fits with previous estimates from observations in the field (Steele and Randolph 1985) and arenas (Randolph and Storey 1999), which indicated a maximum questing period of about 120 days for nymphs.

The thermal sensitivity of metabolic rate, often described by an organism's $\mathrm{Q}_{10}$, is the magnitude of change in metabolic rate for a $10{ }^{\circ} \mathrm{C}$ change in temperature. In insects, $\mathrm{Q}_{10}$ values range from 1.5 to 3 , with a mode of 2.5 (Woods et al. 2003). Here, $\mathrm{Q}_{10}$ values were 1.5 for nymphs, 1.71 for males and 1.63 for females. These values are relatively low, and this reflects the low metabolic rate that helps to increase survival during the extended inter-feed intervals. It has previously been suggested that ixodid ticks have a metabolic rate which is typically $13 \%$ below that of most arthropods (Lighton and Fielden 1995). Why the metabolic rate of nymphs was lower than those of adults is unclear, but it may be that metabolic rate increases in response to the degree of resource depletion, which leads to higher levels of questing activity.

Temperature is considered the most important factor influencing the initiation of $I$. ricinus. For questing, a maximum daily air temperature of $7-8{ }^{\circ} \mathrm{C}$ has been proposed as necessary (MacLeod,1935). In constant-temperature laboratory trials, the minimum threshold temperature for metabolic activity was estimated to be $5.7{ }^{\circ} \mathrm{C}$ for populations derived from Scotland, $7.9{ }^{\circ} \mathrm{C}$ for Wales, $7.0{ }^{\circ} \mathrm{C}$ for England, $9.3{ }^{\circ} \mathrm{C}$ for France at low altitude, and $6.9{ }^{\circ} \mathrm{C}$ for France at high altitude (Tomkins et al. 2014; Perret et al. 2000) found that questing ticks were always collected when the temperature reached or exceeded $5.2{ }^{\circ} \mathrm{C}$. Environmental conditions with relative humidity higher than $45 \%$ and an ambient temperature exceeding $2.5^{\circ} \mathrm{C}$ were considered to be required for questing by I. ricinus (Hubalek et al. 2003). Some element of genetic variation reflecting local adaptation is also evident (Gilbert et al. 2014). Here, however, assuming that a linear extrapolation from the observed temperature range is appropriate, the data presented suggest that the lower threshold for metabolic activity is between -10 and $-5^{\circ} \mathrm{C}$, which is probably close to the lower lethal temperature of this species. An understanding of the lower lethal temperatures and the fact that that metabolic activity is likely to be occurring even at temperatures below the threshold for questing may help to refine attempts to model tick phenology using climate simulations, as it helps to define the climate envelope within which this species can survive. Further work explicitly examining tick metabolism at low temperatures would therefore be of value. Interestingly, complex relationships between metabolite concentrations and pathogen infection and transmission may also occur (Herrmann et al. 2013) and require more detailed consideration in tick-borne disease models.

Acknowledgements The authors wish to thank colleagues in the Veterinary Parasitology and Ecology Group at the University of Bristol for valuable comments on this manuscript and statistical advice. SA would also like to thank the Najran University for funding this work.

Open Access This article is licensed under a Creative Commons Attribution 4.0 International License, which permits use, sharing, adaptation, distribution and reproduction in any medium or format, as long as you give appropriate credit to the original author(s) and the source, provide a link to the Creative Commons licence, and indicate if changes were made. The images or other third party material in this article are included in the article's Creative Commons licence, unless indicated otherwise in a credit line to the material. If material is not included in the article's Creative Commons licence and your intended use is not permitted by statutory regulation or exceeds the permitted use, you will need to obtain permission directly from the copyright holder. To view a copy of this licence, visit http://creativecommons.org/licenses/by/4.0/. 


\section{References}

Abdullah S, Davies S, Wall R (2018) Spectrophotometric analysis of lipid used to examine the phenology of the tick Ixodes ricinus. Parasites Vectors 11:523

Alasmari S, Wall R (2020) Determining the total energy budget of the tick Ixodes ricinus. Exp Appl Acarol 80:531-541

Arrese EL, Soulages JL (2010) Insect fat body: energy, metabolism, and regulation. Annu Rev Entomol 55:207

Belozerov VN (2009) Diapause and quiescence as two main kinds of dormancy and their significance in life cycles of mites and ticks (Chelicerata: Arachnida: Acari) Part 2.\&nbsp;Parasitiformes. Acarina $17: 3-32$

Bowman AS, Dillwith JW, Sauer JR (1996) Tick salivary prostaglandins: presence, origin and significance. Parasitol Today 12:388-396

Burtis JC, Sullivan P, Levi T, Oggenfuss K, Fahey TJ, Ostfeld RS (2016) The impact of temperature and precipitation on blacklegged tick activity and Lyme disease incidence in endemic and emerging regions. Parasit Vectors 9:606

Burtis JC, Fahey TJ, Yavitt JB (2019) Survival and energy use of Ixodes scapularis nymphs throughout their overwintering period. Parasitology 146:781-790

Chown SL, Nicolson S (2004) Insect physiological ecology: mechanisms and patterns. OUP, Oxford

Cuber P, Urbanek A, Naczk A, Stepnowski P, Gołębiowski M (2016) Seasonal changes in the fatty acid profile of the tick Ixodes ricinus (Acari, Ixodidae). Exp Appl Acarol 69:155-165

Diehl PA, Aeschlimann A, Obenchain FD (1982) Tick reproduction: oogenesis and oviposition. In: Obenchain FD, Galun R (eds) The physiology of ticks. Pergamon Press, Oxford

Gilbert L, Aungier J, Tomkins JL (2014) Climate of origin affects tick (Ixodes ricinus) host-seeking behaviour in response to temperature: implications for resilience to climate change? Ecol Evol 4:1186-1198

Gray JS, Dautel H, Estrada-Peña A, Kahl O, Lindgren E (2009) Effects of climate change on ticks and tickborne diseases in Europe. Interdiscip Perspect Infect Dis 2009:593232

Gray JS, Kahl O, Lane RS, Levin ML, Tsao JI (2016) Diapause in ticks of the medically important Ixodes ricinus species complex. Ticks Tick Borne Dis 7:992-1003

Hancock PA, Brackley R, Palmer SC (2011) Modelling the effect of temperature variation on the seasonal dynamics of Ixodes ricinus tick populations. Int J Parasitol 41:513-522

Herrmann C, Voordouw MJ, Gern L (2013) Ixodes ricinus ticks infected with the causative agent of Lyme disease, Borrelia burgdorferi sensu lato, have higher energy reserves. Int J Parasitol 43:477-483

Horn M, Nussbaumerova M, Sanda M, Kovarova Z, Srba J, Franta Z, Sojka D, Bogyo M, Caffrey CR, Kopacek P, Mares M (2009) Hemoglobin digestion in blood-feeding ticks: mapping a multipeptidase pathway by functional proteomics. Chem Biol 16:1053-1063

Hubalek Z, Halouzka J, Juricova Z (2003) Host-seeking activity of ixodid ticks in relation to weather variables. J Vector Ecol 28:159-165

Kongsuwan K, Josh P, Zhu Y, Pearson R, Gough J, Colgrave ML (2010) Exploring the midgut proteome of partially fed female cattle tick (Rhipicephalus (Boophilus) microplus). J Insect Physiol 56:212-226

Lighton JR, Fielden LJ (1995) Mass scaling of standard metabolism in ticks: a valid case of low metabolic rates in sit-and-wait strategists. Physiol Zool 68:43-62

MacLeod J (1935) Ixodes ricinus in relation to its physical environment. II. The factors governing survival and activity. Parasitology 27:123-144

Moraes J, Galina A, Alvarenga PH, Rezende GL, Masuda A, da Silva Vaz Jr I, Logullo C (2007) Glucose metabolism during embryogenesis of the hard tick Boophilus microplus. Comp Biochem Phys Part A 146:528-533

Needham GR, Teel PD (1991) Off-host physiological ecology of ixodid ticks. Annu Rev Entomol 36:659-681

Ogden NH, Lindsay LR, Beauchamp G, Charron D, Maarouf A, O'Callaghan CJ, Waltner-Toews D, Barker IK (2004) Ixodes scapularis (Acari: Ixodidae) in the laboratory and field. J Med Entomol 41:622-633

Perret JL, Guigoz E, Rais O, Gern L (2000) Infuence of saturation defcit and temperature on Ixodes ricinus tick questing activity in a Lyme borreliosis-endemic area (Switzerland). Parasitol Res 86:554-557

Randolph SE (2004) Tick ecology: processes and patterns behind the epidemiological risk posed by ixodid ticks as vectors. Parasitology 129:S37-S65

Randolph SE, Storey K (1999) Impact of microclimate on immature tick-rodent host interactions (Acari: Ixodidae): implications for parasite transmission. J Med Entomol 36:741-748

Randolph SE, Green RM, Hoodless AN, Peacey MF (2002) An empirical quantitative framework for the seasonal population dynamics of the tick Ixodes ricinus. Int J Parasitol 32:979-989 
Satake SI, Kawabe Y, Mizoguchi A (2000) Carbohydrate metabolism during starvation in the silkworm Bombyx mori. Arch Insect Biochem Physiol 44:90-98

Steele GM, Randolph SE (1985) An experimental evaluation of conventional control measures against the sheep tick, Ixodes ricinus (L.) (Acari: Ixodidae). I. A unimodal seasonal activity pattern. Bull Entomol Res 75:489-499

Tomkins JL, Aungier J, Wade Hazel W, Gilbert L (2014) Towards an evolutionary understanding of questing behaviour in the tick Ixodes ricinus. PLoS ONE 9:e110028

Van Handel E (1985a) Rapid determination of glycogen and sugars in mosquitoes. J Am Mosq Control Assoc 1:299-301

Van Handel E (1985b) Rapid determination of total lipids in mosquitoes. J Am Mosq Control Assoc $1: 302-304$

Williams JP, Sauer JR, McNew RW, Hair JA (1986) Physiological and biochemical changes in unfed lone star ticks, Amblyomma americanum (Acari: Ixodidae) with increasing age. J Med Entomol 23:230-235

Woods HA, Makino W, Cotner JB, Hobbie SE, Harrison JF, Acharya K, Elser JJ (2003) Temperature and the chemical composition of poikilothermic organisms. Funct Ecol 17:237-245

Publisher's Note Springer Nature remains neutral with regard to jurisdictional claims in published maps and institutional affiliations. 